\title{
DARVIES RASJIDIN DAN PERUBAHAN KARYANYA SEBUAH KAJIAN SOSIOHISTORIS
}

\author{
Nessya Fitryona ${ }^{1^{*}}$, Maltha Kharisma ${ }^{2 *}$ \\ Program Studi Pendidikan Seni Rupa Jurusan Seni Rupa Fakultas Bahasa dan Seni \\ Universitas Negeri Padang \\ Jl. Prof. Dr. Hamka, Air Tawar Padang, Kel. Air Tawar Barat, Kec. Padang Utara, Kota Padang, Kode Pos 25171 \\ Sumatera Barat. Indonesia \\ Email: nessyafitryona@gmail.com, maltha.kharisma@fbs.unp.ac.id
}

\begin{abstract}
Abstrak
Penelitian ini bertujuan mengeksplanasikan latar belakang perjalanan berkesenian Darvies Rasjidin dan faktor-faktor yang memengaruhi perubahan karyanya. Darvies merupakan seniman asal Sumatra Barat yang saat ini bermukim di Yogyakarta. Sekitar pertengahan tahun 70-an karyanya berbeda dari arus maistream yang berkembang di Sumatra Barat yaitu surealistik bertemakan Minang. Namun pada periode selanjutnya, ia memutuskan hijrah ke Yogyakarta. Karyanya mengalami perubahan dalam corak ke arah yang lebih kontemporer. Metode penelitian yang digunakan adalah kualitatif bersifat analisis deskriptif dengan pendekatan sosiohistoris. Data penelitian diperoleh dengan cara wawancara, penjelajahan arsip berupa kliping koran, dan dokumentasi karya seni. Hasil penelitian menunjukkan latar belakang Darvies Rasjidin dalam perjalanan berkeseniannya tidak terlepas dari lingkungan keluarga, institusi sosial seni serta peran pelaku sosial yang mendukung proses kreatifnya. Selanjutnya, perubahan karya-karya Darvies Rasjidin dalam perjalanan berkeseniannya dipengaruhi oleh faktor tuntutan ekonomi, lingkungan sosial, dan iklim berkesenian yang berbeda antara di Sumatra Barat dan Yogyakarta.
\end{abstract}

Kata Kunci: sosiohistoris, seni lukis.

\begin{abstract}
This study aims to explain the background of Darvies Rasjidin's artistic journey and the factors that influence the changes in his work. Darvies is an artist from West Sumatra who currently resides in Yogyakarta. Around the mid-70s his work was different from the current maistream that developed in West Sumatra, namely the Minang-themed surrealist. However, in the next period, he decided to move to Yogyakarta. His work changed style to a more contemporary. The research method used is qualitative descriptive analysis with a sociohistorical approach. The research data were obtained by means of interviews, browsing archives in the form of newspaper clippings, and documentation of works of art. The results showed that Darvies Rasjidin's background in his artistic journey was inseparable from his family environment, social arts institutions and the role of social actors who supported his creative process. Furthermore, the changes in Darvies Rasjidin's works in his artistic journey are influenced by factors of different economic demands, social environment, and artistic climate between West Sumatra and Yogyakarta.
\end{abstract}

Keywords: sociohistorical, art painting.

\section{PENDAHULUAN}

Konstruksi seni rupa dibentuk melalui eksponeneksponen yang terlibat dalam dunia seni. Salah satunya adalah perjalanan seniman dan karyanya. Seniman merupakan pelaku dalam produksi karya sebagai artefak yang mampu berperan menjadi fakta sejarah, fakta sosial dalam rekam jejak capaian kreativitas seni rupa dan wacana pada fragmen-fragmen periode yang dapat diamati. Pengamatan fragmen wacana dan pencapaian seniman ini dapat dilakukan dengan penelusuran seniman dan karyanya yang aktif berperan dalam perjalanan seni rupa di suatu wilayah.
Tinjauan karya seni dan seniman sebagai upaya pendokumentasian perjalanan berkesenian seniman masih menjadi hal yang sangat dibutuhkan terutama di wilayah Sumatra Barat. Hal ini menjadi penting agar transfer wacana dan seniman-seniman yang andil dalam membangun perjalanan berkesenian suatu wilayah dapat dikenal dan diakui tidak hanya pada segelintir generasi. Salah satu di antara daftar nama perupa yang perlu dicatat perjalanan berkeseniannya adalah Darvies Rasjidin. 
Darvies Rasjidin merupakan pelukis asal Sumatra Barat generasi 50-an. Dalam menjalani profesi sebagai seniman, Darvies memiliki keterbatasan fisik dalam berkarya. Ia hanya melukis dengan tangan kanannya saja, karena tangan kirinya terpaksa diamputasi saat ia berusia remaja. Namun, terdapat fakta menarik yang tercatat dalam jejak perjalanan berkeseniannya.

Pada periode 70-an hingga 90an, Darvies diketahui masuk ke dalam daftar nama seniman yang menonjol dan kerap diperbincangkan dalam media surat kabar. Moenir pada tahun 1979 mengungkapkan perkembangan corak dan aliran seni rupa di Sumatra Barat pada gelombang setelah pulangnya para perupa yang melanjutkan studi di perantauan semakin beragam. Di antara mereka ada yang membawa aliran abstrak, dadais, hingga surealis. Corak dan aliran tersebut saat itu dirasakan sulit untuk dipahami. Aliran yang menonjol tersebut terapat pada lukisan Wisran Hadi, A.Alin De, dan Darvies Rasjidin (Haluan, 3 Juli 1979).

Pelukis asal Sumatra Barat lainnya pada tahun 70-an banyak yang memakai representasi identitas alam dan sosiokultural Minang dalam karyanya. Hal ini terlihat pada karya Amir Syarif, Idran Wakidi, A.R. Nizar, dan Yazid. Namun, Darvies mempresentasikan karya lukisan dengan gaya yang khas, yaitu surealis ala Minang. Karya-karyanya saat itu bertemakan mitos dan simbol Minangkabau. Karyanya bertemakan tambo/ legenda/ filosofi Minangkabau, seperti cerita cindua mato, Si Binuang, hakekat mamak kemenakan, gadis Minang, niniak mamak, pangulu dan fenomena sosial lainnya. Seperti yang diungkap Yurnaldi, keberadaan karyanya saat itu mendapat apresiasi hingga tahun 90an. Karya-karyanya mengindikasikan ia merupakan satu-satunya pelukis corak surealis yang menyajikan kebaruan dalam iklim berkesenian Sumatra Barat (Haluan, 7 Juli 1992).

Di sisi lain, karya Darvies pernah mendapat kritikan dalam menampilkan wacana surealis yang berciri khas tema Minangkabau. Karya surealis Minang Darvies mendapat tanggapan negatif dari salah satu tokoh masyarakat, yaitu dari ketua LKAM (Lembaga Kerapatan Adat Minangkabau) di Padang. Karya yang memvisualisasikan orang Minang yang retak dan tanpa kepala. Ketua LKAM tersebut menduga bahwa Darvies mengungkapkan sesuatu yang menyindir keberadaan orang Minang, bahwa orang Minang berjalan dan berprilaku tidak memakai pikirannya. Karya tersebut kemudian dikatakan karya yang memalukan orang Minang dan memiliki kualitas yang jelek (Haluan, 24 September 1996).
Pada tahun 1998, Darvies memutuskan untuk tinggal dan menetap di Yogyakarta. Setelah memutuskan untuk berdomisili di Yogyakarta. Visual lukisan Darvies menampilkan visual yang berbeda. Banyak terjadi perubahan pada karyanya secara perlahan. Ia tidak lagi konsisten dengan corak surealis Minang yang telah mendapat pencapaian yang diakui oleh masyarakat di Sumatra Barat sebelumnya. Objek-objek visual karakter khas dari surealis Darvies yang bersifat keminangan secara visual mulai jarang dimunculkan ke atas kanvasnya.

Berangkat dari latar belakang dan beberapa temuan fakta fenomenal yang telah dipaparkan di atas, maka penulis tertarik untuk melakukan penelitian sekaligus pencatatan rekam jejak berkesenian Darvies dengan judul "Darvies Rasjidin dan perubahan karyanya : sebuah kajian sosiohistoris." Penelitian ini menelusuri permasalahan yang berkaitan tentang latar belakang perjalanan berkesenian yang dilakukan Darvies Rasjidin dan faktor-faktor yang memengaruhi perubahan dalam karyanya.

\section{KAJIAN TEORI}

Penelitian ini menggunakan teori sosiologi dan sejarah untuk membantu menelusuri jawaban atas pertanyaan yang telah dikemukakan. Teori sosiologi digunakan untuk menelusuri latar belakang sosial terjadinya proses penciptaan karya dalam praktik berkesenian Darvies Rasjidin dan hubungannya dengan jaringan serta relasi sosial seni yang saling memengaruhi dalam medan seni rupa seniman. Sehingga hal tersebut mengerucut pada faktor-faktor yang berperan dalam perjalanan dan perubahan Darvies dalam berkarya. Selanjutnya, teori sejarah digunakan untuk memahami perubahan-perubahan yang terjadi berdasarkan urutan waktu secara kronologis.

Salah satu hal yang penting dari penciptaan seni adalah proses sosial, penciptaan status, dan tujuan karya seni tertentu dipilih dan diciptakan untuk dimasukkan di dalam prinsip berkesenian seniman. Zolberg (1990 : 9) mengemukakan konstruksi seni dibentuk dari institusi sosial, seniman, dan masyarakat. Artinya, fenomena kesenian yang terjadi dapat dipengaruhi oleh tiga faktor besar tersebut, yang nyata ada di dalam kehidupan seniman.

Penelitian ini juga menggunakan teori sejarah. Esensi dari sejarah adalah waktu, sehingga dalam penulisan sejarah diperlukan periodesasi. Hal ini dapat mempertegas bentuk dan struktur pada waktu secara konsisten (Kartodirdjo, 1993 : 78). Kriteria pembagian ini dibagi berdasarkan peran aktif pelaku seni dalam 


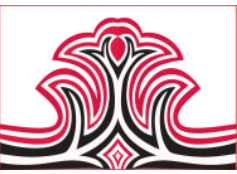

proses pencapaian artistik Darvies dalam rentang waktu yang diteliti.

\section{METODE PENELITIAN}

Metode yang dipakai adalah kualitatif bersifat analisis deskriptif. Sumber data yang digunakan dalam penelitian ini adalah data primer dan data sekunder. Pengumpulan data di lapangan dilakukan dengan observasi langsung melalui wawancara sebagai data primer. Wawancara dilakukan langsung dengan Darvies Rasjidin di Yogyakarta. Selanjutnya data sekunder diperoleh melalui penelusuran arsip katalog, dan kliping media masa serta penelusuran karya-karya Darvies Rasjidin baik reproduksi penulis dari dokumentasi pribadi seniman dan katalog.

Analisis data dilakukan menggunakan model miles dan Huberman yang terdiri dari reduksi data, display/penyajian data, dan pengambilan kesimpulan atau verifikasi (Denzin, 2009 : 692). Reduksi data dilakukan dengan menyeleksi temuan data penelitian yang direkam dan kumpulan catatan lapangan. Data diseleksi berdasarkan fokus masalah yang diteliti yaitu latar belakang perjalanan berkesenian Darvies Rasjidin dan faktor-faktor yang memengaruhi perubahan karyanya. Selanjutnya data didisplay dalam bentuk teks naratif dan disusun secara sistematis. Langkah terakhir yaitu mengambil kesimpulan yang kemudian diuji kembali dengan merefleksikan data-data pendukung di lapangan.

\section{HASIL DAN PEMBAHASAN}

\section{Hasil}

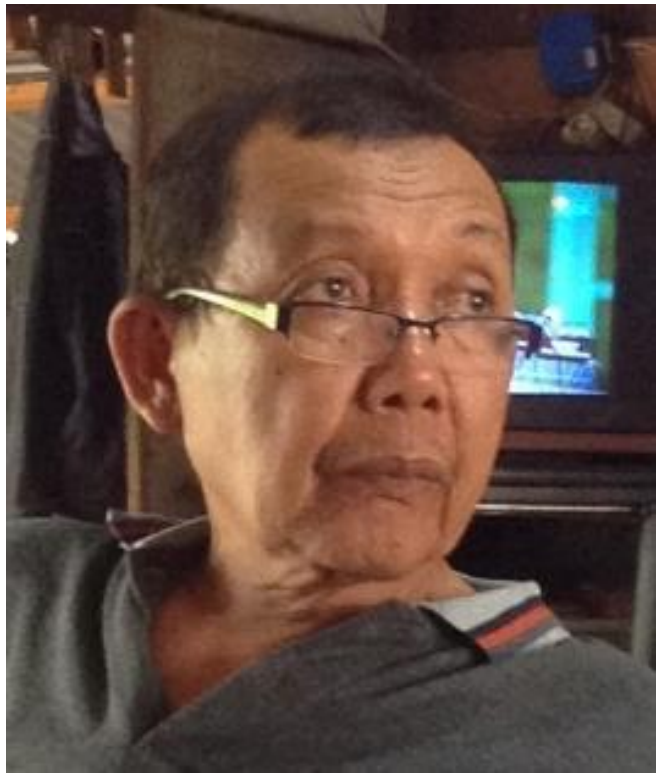

Gambar 1. Potret Darvies Rasjidin (Rasjidin, 2018)
Gorga : Jurnal Seni Rupa

Volume 10 Nomor 01 Januari-Juni 2021

p-ISSN: 2301-5942 | e-ISSN: 2580-2380

Darvies Rasjidin merupakan pelukis asal Sumatra Barat, kelahiran Solok, 15 Oktober 1948 dari pasangan suami-istri Rasjidin dan Jalinus Jamin. Darvies berada dalam keluarga Minang yang sederhana. Ayah Darvies merupakan seorang Pangulu di tanah kelahiran ayahnya Talawi, Sawah Lunto, Sumatra Barat. Ia pensiunan tentara dan bekerja menjadi wartawan di surat kabar Haluan. Menurut garis keturunannya, tidak terdapat seorang pun yang berprofesi dalam bidang seni di keluarganya. Darvies merupakan anak pertama dari dua bersaudara, memiliki adik perempuan bernama Edimar Rasjidin kelahiran tahun 1952, yang selanjutnya berprofesi sebagai guru jurusan dekorasi di SMSR (Sekolah Menengah Seni Rupa) Padang.

Saat berusia kanak-kanak Darvies sudah memulai hobi menggambar dengan suka mencoret-coret dinding rumah panggungnya di Solok dengan arang dan kapur warna. Proses latihan kepiawaian tangannya dalam mengendalikan garis secara berkelanjutan. Namun, saat itu ia belum terfikir untuk menjadi seorang pelukis. Di bangku sekolah dasar, kemampuan menggambarnya lebih menonjol dibanding teman-temannya. Karya gambarnya mendapat apresiasi khusus dari guru dan teman-temannya. Motivasi ini mengarahkan Darvies melanjutkan pendidikan ke Sekolah Teknik Mesin setara dengan sekolah menengah pertama, di Solok. Satu tahun mengeyam pendidikan, pada tahun 1964, diwaktu ujian naik kelas dua, ia mendapat kecelakaan jatuh dari pohon yang membuatnya kehilangan tangan kirinya secara permanen (wawancara, 3 Oktober 2014).

Setelah menamatkan sekolah teknik, Darvies berminat melanjutkan keahliannya ke STM (Sekolah Teknik Mesin) setara dengan Sekolah Menengah Atas di Solok. Pihak sekolah mengakui potensi menggambarnya baik. Namun pihak sekolah meragukan kemampuannya dalam hal berpraktik nantinya saat bersekolah, karena cacat fisik yang dimilikinya. Dengan berbagai pertimbangan, ia tidak diterima sebagai siswa di sekolah tersebut (wawancara, 22 November 2014). Akhirnya Darvies memilih melanjutkan sekolah ke SSRI di Padang atas solusi dari Ayahnya. Berdasarkan iklan yang tertera pada surat kabar Haluan mengenai penerimaan calon siswa di SSRI (Sekolah Seni Rupa Indonesia) Padang, akhirnya Darvies pun hijrah ke Padang dan melamar untuk melanjutkan sekolah di sana. Ia diterima dan mulai mengenal dunia seni lukis.

SSRI atau Sekolah Seni Rupa Indonesia dulunya adalah satu-satunya sekolah kejuruan di Sumatra dan merupakan institusi seni yang ke-4 yang pernah didirikan di Sumatra Barat setelah Kweekschool pada 
tangga 1 April 1856 di Bukittinggi, INS (Indische Nederland School) pada tanggal 31 Oktober 1926 di Kayu Tanam dan Jurusan Seni Rupa, Fakultas Keguruan dan Ilmu Pendidikan (FKIP) Unand (sekarang IKIP/UNP Padang) pada tahun 1963. Darvies merupakan angkatan ke-3 sejak dirikannya SSRI pada pada tanggal 25 September 1965 di Padang. Saat itu SSRI dipimpin oleh Hasnul Kabri. Pada tahun 1968, Darvies mulai belajar melukis cat minyak dan intensif mengenal seni lukis. Ia memulai mengikuti pameran bersama dengan siswa SSRI lainnya selama tahun 1969 - 1970. Pada tahun 1971, Darvies tamat dari SSRI Padang.

Pada Tahun 1973 Darvies melanjutkan sekolah ke ASRI Yogyakarta. Namun, satu tahun sebelum keberangkatanya, ia sempat mencari uang untuk bisa merantau. Kehidupan keluarga yang sederhana menuntutnya untuk menjadikan bakat menggambarnya bisa menghasilkan uang. Ia bekerja sebagai pengisi kolom ilustrasi komik di Surat Kabar Haluan. Karyanya sempat diterbitkan sebanyak tiga kali di Surat Kabar. (wawancara, 23 November 2014).

Saat itu, Darvies memiliki teman dekat yang bernama Risman Marah yang juga alumni dari SSRI Padang. Risman telah lebih dulu bersekolah di ASRI Yogyakarta. Banyak siswa tamatan SSRI melanjutkan sekolah ke Akademi Seni Rupa Indonesia (ASRI) Yogyakarta atas rekomendasi dari para pendiri SSRI yang juga alumni dari STSRI/ASRI Yogyakarta. Satu tahun selanjutnya, ketika ia mendapat kabar penerimaan siswa baru di ASRI Yogyakarta dari Risman Marah, Darvies pun memberanikan diri untuk berangkat ke Yogyakarta melalui jalur kapal dari pelabuhan Teluk Bayur ke Pelabuhan Merak.

Ketika sampai di Yogyakarta dengan penuh perjuangan, Darvies menginap di rumah Risman di kawasan Taman Sari. Satu hari menginjakkan kaki di Yogyakarta, ia langsung melaksanakan tes masuk di ASRI Yogyakarta. Namun takdir berkata lain, ia diumumkan tidak lolos seleksi. Karena keinginan Darvies yang besar, ia menemui direktur ASRI yang saat itu dijabat oleh Abas AliBasyah. Awalnya Abas tidak menerima, namun akhirnya dengan segala usaha Darvies, ia di terima di jurusan seni grafis dengan syarat. Jika nilainya bagus, ia diperbolehkan pindah ke jurusan lukis pada satu semester berikutnya. Sambil bersekolah, Darvies bekerja di kios tukang jahit Sumbar yang kebetulan pemiliknya juga orang asal Sumatra Barat. Hal ini ia lakukan untuk menyangga kehidupannya di perantauan. Di sana Darvies bekerja memperbaiki mesin jahit.
Tinggal di Yogyakarta dan mengenyam pendidikan di ASRI Yogya telah merubah kreatifitas keseniannya dan kehidupan Darvies menjadi bohemian dengan penampilan Darvies yang gondrong dan baju compangcamping. Situasi tersebut diketahui orang yang satu kampung dengan Darvies. Kabar tersebutpun sampai ke kampung halamannya. Kehidupan Darvies di Yogyakarta dikira orang tuanya sengsara. Ia kemudian dipanggil untuk pulang dengan alasan orang tuanya sakit. Setelah Darvies diberi ongkos pulang, dan ia kembali ke Padang pada tahun 1975 dan tidak diberikan kesempatan untuk menyelesaikan sekolahnya di ASRI Yogyakarta.

Setelah Darvies kembali ke Padang tanpa kegiatan apapun ia memilih untuk berkunjung ke Pusat Kesenian Padang atau disebut PKP (sekarang berubah menjadi Taman Budaya Padang). Sebelumnya pada tahun 1972, Lokasi PKP dimanfaatkan Pemerintah Daerah Tingkat II Kotamadya Padang untuk pengelenggaraan kegiatan Padang Fair. Kegiatan tersebut dilaksanakan untuk promosi dagang dan industri tahunan di Sumatra Barat, penampilan berbagai macam atraksi kesenian modern dan tradisi. Selanjutnya lokasi tersebut direkomendasikan pada seniman, dan budayawan untuk menjadi Pusat Kesenian Padang (PKP). Rekomendasi tersebut mendapat dukungan dari BHR. Tanjung (dramawan) dan Arby Samah (perupa) jserta para seniman muda yang juga mempergunakan area tersebut untuk kegiatan berkesenian.

Tahun 1975 Pemerintah Daerah Tingkat II Kotamadya Padang sepakat untuk untuk mendirikan Pusat Kesenian Padang (PKP) beserta bangunan yang sebelumnya digunakan untuk Padang Fair. PKP saat itu dipimpin oleh Mursal Esten. Ia adalah guru besar di bidang sastra Indonesia di IKIP Padang. Di PKP, banyak sanggar-sanggar seniman yang melakukan aktivitas seni, di antaranya terdapat Sanggar Bumi. Darvies mengisi kegiatannya di sana. Sanggar Bumi Teater merupakan sebuah kelompok seni yang mewadahi kegitan seni meliputi seni rupa, musik, teater, dan kegitan menulis, bertempat di Taman Budaya Padang yang resmi didirikan Wisran Hadi pada tahun 1978. Di sanggar tersebut, Darvies bermain teater dan melukis.

Sanggar Bumi Teater pada masa jayanya banyak diminati oleh kalangan siswa-siswa yang memiliki perhatian pada seni. Sanggar Bumi sempat beranggotakan ratusan siswa dari bebagai asal sekolah. Sanggar tersebut diasuh oleh beberapa orang seniman dan sastrawan Sumatra Barat seperti, Wisran Hadi, sebagai pendiri, Upita Agustin, Rozak Taib, Hamid 
Jabar, Damar Moenir, dan Haris Efendi. Pada saat di Sanggar Bumi Teater, Darvies sempat membentuk kelompok kecil yang diberi nama "Teater Diponegoro" (Teater D) bersama teman-temannya. Ia sempat mendapat kesempatan bermain teater di Jakarta. Saat itu, ia mendapat biaya akomodasi dari pemerintah. Peran yang ia pernah mainkan Darvies dalam beberapa naskah pertunjukkan yaitu "Anggun Nan Tongga”, “Cindua Mato”, “Imam Bonjol”, “Nan Renceh”, dan "Perguruan”.

Darvies bermain teater untuk mendapat uang dalam menyangga kehidupan melukisnya. Di Jakarta ia menyempatkan diri untuk membeli cat lukisan di "Gunung Agung” Jakarta. Saat itu ia belum mengenal akrilik dan masih menggunakan cat berbasis minyak. Cat minyak saat itu masih tergolong mahal dan langka di Padang. Sehingga hanya sedikit orang memilih untuk menjadi seorang pelukis dan kalaupun melukis kebanyakan seniman selain Darvies saat itu menggunakan kanvas berukuran kecil.

Di bidang seni rupa, Darvies dan teman-temannya juga membentuk kelompok kecil yaitu, Herisman Is, A.A. Lin De, dan Tamsil Rosa. Lukisan yang mengambil tema Minangkabau sebagai tema lukisannya. Konsep kesenian Darvies tidak lepas dari lingkungan sekitarnya yakni tradisi Minangkabau. Saat itu selain berteater Wisran Hadi juga ikut melukis dengan corak naturalis (wawancara, 23 November 2014).

Pada tahun 1979, Darvies berpameran tunggal yang pertama di Taman Budaya Padang. Namun pada saat itu, karya-karya yang dipamerkan masih sedikit menyajikan karya-karya surealis. Pada awalnya, Darvies cenderung memamerkan karya surealisnya di Jakarta, saat mengadakan pameran bersama dengan teman-teman pelukis lainnnya di Sanggar Bumi di Taman Ismail Jakarta. Terdapat dua karyanya yang menjadi koleksi Taman Ismail Marzuki, yaitu Yang Tersisa (1996) dan Pemusik (2000). Pada tahun 1992, pameran bersama Asri Rosidi di Padang Darvies kemudian memamerkan karya Minang yang retak.

Karya pertamanya corak surealisnya adalah "Perjalanan Si Binuang" (1974) mempresentasikan kerbau si Binuang yang patah tanduak dengan representasi visual yang retak dan rapuh. Saat itu karyanya menuai kritikan dari pemuka Adat di Padang yang diduga mencemooh masyarakat dan kebudayaan Minangkabau (Haluan, 24 September 1996).

Pada tahun 1998, Darvies memutuskan pindah ke Yogyakarta meniti karir keseniannya. Hal ini juga diperkuat dengan dukungan teman dekatnya di SSRI, Risman Marah yang juga saat itu sudah menetap dan meniti karir di Yogyakarta setelah taman dari ASRI Yogya. Setelah memutuskan untuk pindah ke Yogyakarta, Darvies menyelenggarakan pameran tunggal kedua pada tahun 2000 di Benteng Van Derburg. Karya yang dipamerkan masih seputar karya yang pernah dibuat di Padang tahun 90-an dan dibawa berpameran di Yogyakarta. Pada perkembangan selanjutnya Darvies bergabung dalam komunitas seni yang terdiri dari seniman perantauan Minang di Yogyakarya, yaitu Komunitas Seni Sakato. Pada kesempatan selanjutnya, Darvies aktif berkarya dan ikut serta dalam even pameran seni yang diselenggarakan Komunitas ini.

\section{Pembahasan}

\section{1). Latar Belakang Perjalanan Berkesenian}

Berpijak dari landasan teori Zolberg, bahwa konstruksi seni dibentuk dari peran institusi sosial, seniman, dan masyarakat. Maka, dukungan kelembagaan berkaitan dengan institusi sosial yang memiliki peran dalam membentuk seniman dan karyanya. Dalam hal ini Institusi sosial membentuk seniman sesuai dengan arah tujuan, kepentingan, dan kapasitasnya masing-masing. Para sosiolog memahami seniman memiliki bakat berkat dukungan kelembagaan dan keterbatasan di sekitar produksi budaya secara lebih umum. Mereka adalah orang yang mengambil bagian di sekitar seniman sebagai pemain peran yang memiliki posisi nyata di dalam masyarakat dan berada dalam proses konstruksi (Zolberg, 1990 : 110).

Dukungan kelembagaan dan institusi sosial yang diperoleh Darvies dalam latar belakang proses perjalanan berkeseniannya dimulai sejak ia melanjutkan sekolah sesuai dengan kegemarannya dalam menggambar, yaitu di SSRI Padang. Di sana ia mulai memperdalam dan mengenal dunia seni lukis. Saat di SSRI, Darvies merupakan teman satu angkatan dengan Risman Marah. Ia selanjutnya banyak memberikan dukungan pada perjalanan keseniannya. Teman-teman satu angkatan lainya adalah Darman Moenir yang dikenal sebagai penulis, Armansyah Nizar (Ilustrator Surat Kabar Haluan), dan Yose Rizal dikenal sebagai pelukis naturalis.

Saat mengenyam pendidikan di SSRI Padang ia bertemu dengan guru lukis, yaitu Amir Syarif. Ia banyak diperkenalkan dengan teknik-teknik menggambar dan melukis. Selain itu, ia juga berkunjung ke rumah beberapa pelukis naturalis yang saat itu cukup berpengaruh dan menjadi panutan saat itu, yaitu Wakidi dan A.Arifn. 


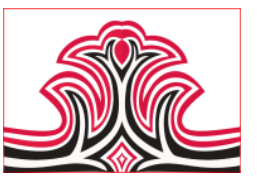

Selanjutnya yang melatar belakangi perjalanan kekaryaan Darvies adalah ASRI Yogyakarta. Di ASRI Yogyakarta, salah satu teman angkatannya adalah Tulus Waseto. Saat itu di Yogyakarta mulai muncul benih-benih corak surealis yang menjadi inspirasi Darvies. Namun, karyanya sendiri masih berkutat pada karya lukis yang mengutamakan tekstur dan bercorak abstrak figuratif serta kaligrafi dengan media cat minyak.

Pada tahun 1973, ia mengadakan pameran sketsa di Yogyakarta dan beberapa pameran bersama tugas mata kuliah di ASRI Yogyakarta. Ketika menjalani pendidikan di ASRI Yogyakarta cukup membuat modal melukisnya menjadi matang, khususnya sket realis seperti objek manusia, tumbuhan, dan bangunan perkotaan di Yogyakarta. Saat itu ia sering melakukan kegiatan sketsa bersama dengan teman seangkatannya ke kawasan Malioboro dan melakukan pameran dalam rangka tugas perkulihan.

Institusi sosial selanjutnya yang berperan dalam latar belakang kesenian Darvies adalah Sanggar Bumi Teater. Darvies kembali ke Padang setelah berhenti melanjutkan pendidikan di ASRI Yogyakarta. Kemudian ia bergabung dalam sanggar tersebut. Di sana Darvies melukis dan bermain teater. Sanggar ini juga yang berperan mensponsori Darvies untuk berpameran tunggal pada tahun 1979 .

Saat itu Darvies dimotivasi kepercayaan dirinya dan mengikuti pertunjukan teater dan sempat tampil ke Jakarta. Perkenalan dengan Wisran Hadi yang banyak memotivasi dan menginspirasinya untuk bangkit dan maju, serta memberikan kekuatan pada karyanya. Ia salut dengan prinsip yang dipegang Wisran Hadi yaitu "orang bisa, saya juga bisa". dipimpin oleh Hasnul Kabri, Keterkaitan Darvies dengan Sanggar Bumi dalam membangun kreatifitasnya sangat didukung oleh sahabat-sahabatnya sesanggar sebagai rekan yang cukup baik. Sehingga Darvies kala itu memiliki semangat dalam berkarya lukis di Sumatra Barat (Haluan, 3 Juli 1979)

Sekitar tahun 1976 Darvies dalam memperoleh ideidenya dalam berkesenian juga mendapat pengaruh oleh pola pikir Wisran Hadi yang bengkok, yaitu berfikir frontal tentang kebudayaan Minang sendiri. Ia diberikan buku, serta cerita mengenai Minang yang bengkok berdasarkan cerita tambo. Hal ini kemudian menjadi inspirasi Darvies untuk berkarya lukis dengan pemikiran yang secara tidak langsung juga berdampak
Gorga : Jurnal Seni Rupa

Volume 10 Nomor 01 Januari-Juni 2021

p-ISSN: 2301-5942 | e-ISSN: 2580-2380

pada karya Darvies yang kemudian mulai bercorak surealis (wawancara, 23 November 2014).

Objek-objek yang ditampilkan dari identitas tersebut seperti, rumah gadang, beberapa figur perempuan Minang yang memakai baju bundo kanduang, topi bertanduk khas penutup kepala perempuan Minang, selendang, sampai budaya matrilineal yang ditampilkan dalam figur-figur perempuan yang sering direpresentasikan ke dalam visual karyanya dalam corak di luar dunia nyata dan fantasi. Kemudian digarap dalam bentuk wajah-wajah dan tubuh manusia yang seperti terbuat dari batu dalam keadaan melayang di atas kabut dan awan, pecah-pecah, dan retak. Di samping itu, objek manusia kerap dilukiskan dengan mengenakan topeng di wajahnya. Di antaranya terlihat pada lukisan "Perjalanan Si Binuang” (1987), "Pagar Ayu" (1998), "Dialog Empat Wanita" (1998), dan "Kesuburan yang Gersang" (1998). Hal ini menyimbolkan keironian kultural seperti tantanan adat, norma, dan kode etik Minangkabau yang tidak lagi selektif, rancu, dan bersifat telah materialistis.

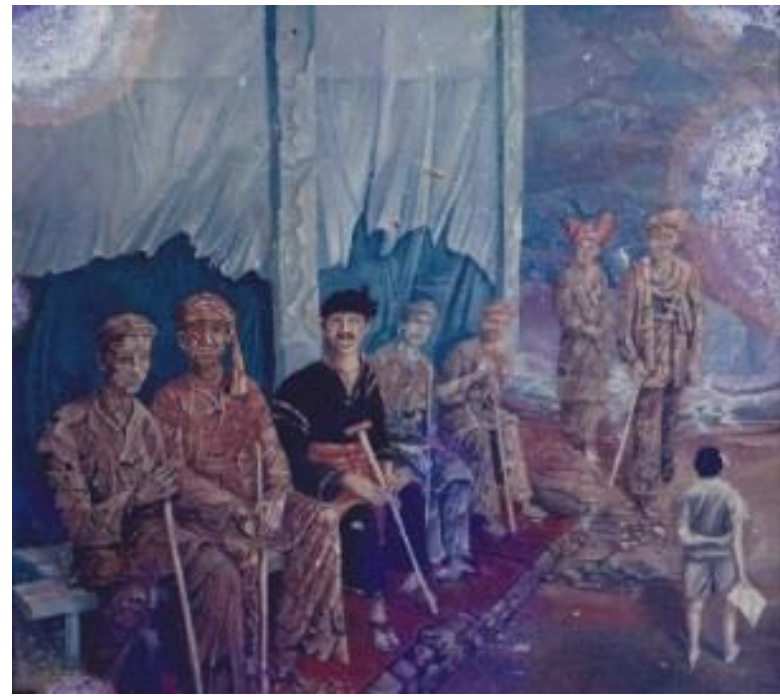

Gambar 2. Lukisan "Tagak Gala” (1987), 85x85 cm (Rasjidin, 2014) 

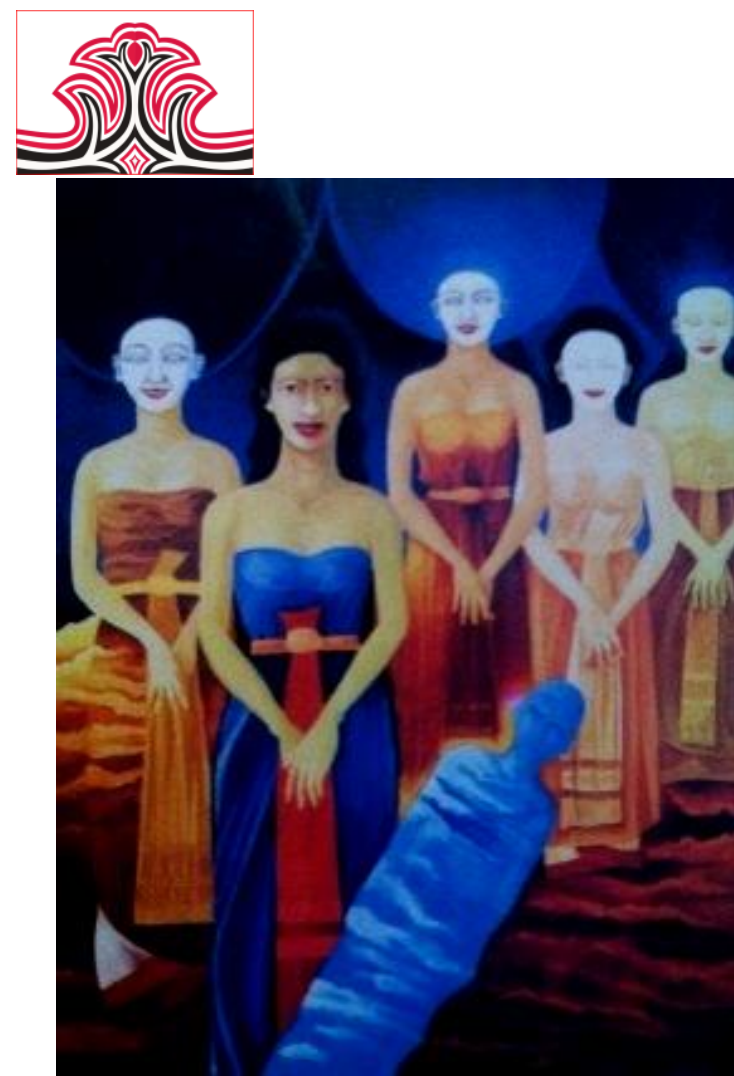

Gambar 3. Di Antara Pilihan (2000), 100 x $130 \mathrm{~cm}$ (Rasjidin, 2014)

Pada perjalanan berkeseniannya selanjutnya, Darvies memilih kembali merantau ke Yogyakarya pada tahun 1998. Institusi Sosial yang berperan selanjutnya adalah Komunitas Seni Sakato. Perlahan karya-karyanya berubah menjadi tema yang minimalis dan bercorak kontemporer. Selain Komunitas Sakato sebagai komunitas besar, Darvies memiliki komunitas kecil yang masih berada dalam wadah komunitas tersebut, yaitu Komunitas Semoet, yang beranggotakan Abdi Setiawan, Jhoni Waldi, Darvies Rasjidin, Khairul El Kamal, Denny Susanto, dan Aidis Sukri. Melalui komunitas ini Darvies melanjutkan eksistensinya dalam melukis.

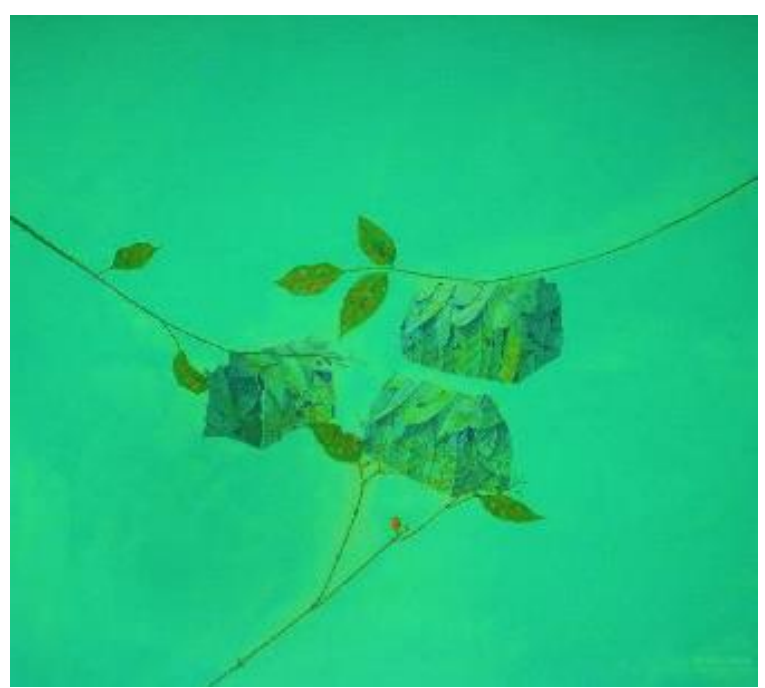

Gambar 4. The House of Leaf (2009), 139 x $158 \mathrm{~cm}$ (Rasjidin, 2014)
Gorga : Jurnal Seni Rupa

Volume 10 Nomor 01 Januari-Juni 2021 p-ISSN: 2301-5942 | e-ISSN: 2580-2380

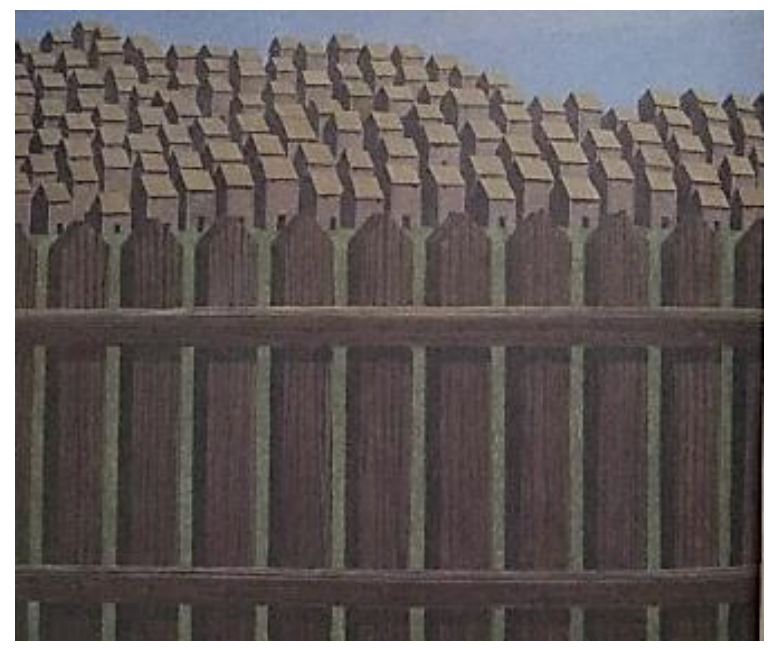

Gambar 5. Pagar Penghabisan (2012), $140 \times 160 \mathrm{~cm}$ Katalog BAKABA\#2, 2012. (Pamola, 2012).

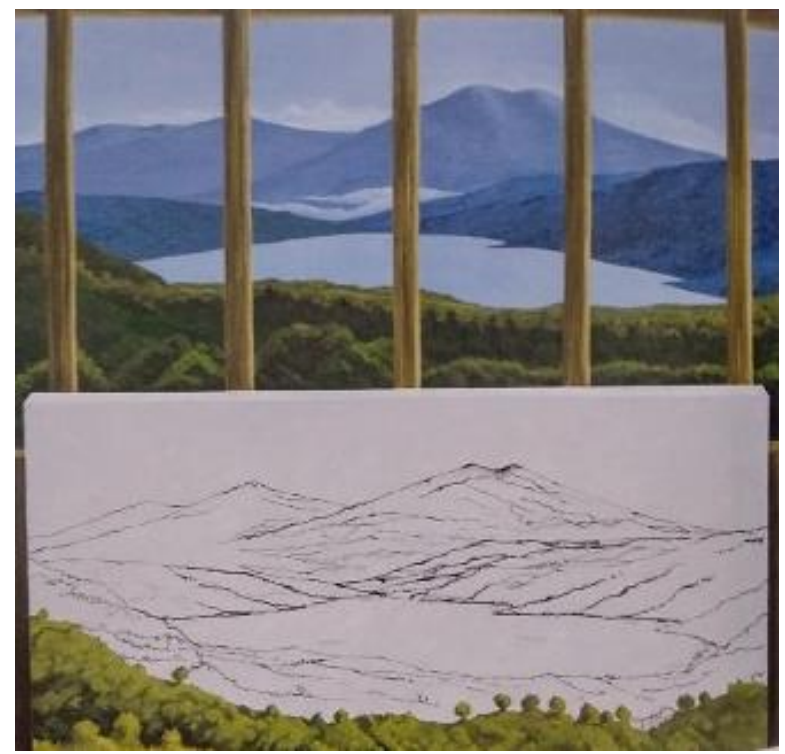

Gambar 6. Sektsa Alam (2016), 140 x $140 \mathrm{~cm}$

Katalog BAKABA\#5, 2016. (Larenz, 2016).

\section{2). Faktor-Faktor yang Memengaruhi Perubahan dalam Karya Darvies Rasjidin}

Meminjam pemikiran Zolberg (1990: 165) mengenai perlu kiranya melihat proses seseorang tertarik menjadi seniman atau memilih seni sebagai karir dibandingkan dengan pekerjaan-pekerjaan lain. Ketertarikan tersebut dapat ditelusuri dari Darvies. Bagi Darvies, melukis saat itu adalah hobi dan hasil pemikirannya tentang fenomena apa yang tampak di sekitarnya. Kecelakaan jatuh dari pohon yang membuatnya kehilangan tangan kirinya telah membimbingnya pada ketertarikannya terhadap dalam dunia melukis walaupun sebelumnya ia telah menyadari bakat yang ada pada dirinya. Arah dirinya untuk menjadi seniman juga mendapat saran dari ayahnya.

Pada periode setelah ia kembali dari Yogyakarta pada tahun 1974, setelah sempat mengenyam pendidikan di ASRI Yogya, ia melakukan pengenalan corak baru 
pada tradisi seni lukis yang telah berkembang lama di Sumatra Barat. Saat itu, tema-tema yang cenderung hadir yaitu pemandangan alam Sumatra Barat eksotik dan liris serta aktivitas kehidupan sosial, figur potret, still life hingga tema religi seperti kaligrafi dan sebagian kecil mengarah pada kritik sosial. Ide-ide itu direpresentasikan ke dalam berbagai pola seni modern universal yang diadaptasi dari ajaran Barat seperti realis, impresif, ekspresif, dekoratif. Sebagian kecil abstrak (Fitryona, 2017: 31). Di antara corak lukisan yang berkembang, lukisan surealis Darvies merupakan fenomena kebaruan semangat kesenian yang khas dalam perkembangan seni lukis di Sumatra Barat. Keberadaan karyanya saat itu mendapat respon dari para penulis dan pemerhati budaya seperti Darman Moenir dengan kerap diulasnya darvies pada tulisan Moenis di kolom surat kabar.

Pengembangan gaya-gaya seni baru di dalam serangkaian perkembangan kesenimanan Darvies mulai terlihat pada tahun 70-an pada saat tergabung di Sanggar Bumi. Darvies mempresentasikan visual untuk apa yang disebut oleh surealis ala Minang dengan idiom budaya Minangkabau. Di dalam membahas kemunculan gaya-gaya ini, setiap penyerangan atas gaya seni akademis yang telah diterima secara resmi, retorika populer cenderung menggunakan representasi alam, realis, naturalis, dadais dan ekspresif. Darvies mengatakan gaya tersebut ia ciptakan juga mendapat stimulus dari seni lukis surelis di Yogyakarta yang saat itu baru mulai tumbuh dan berkembang. Kemudian surealis Minang yang muncul merupakan unsur ketidaksengajaan karena seriring dengan ide yang muncul saat Darvies berada di Sanggar Bumi dan bertemu dengan Wisran Hadi (wawancara, 23 November 2014).

Pertemuan dengan Wisran Hadi yang banyak menginspirasi Darvies dan membelokkannya dalam ideologi berkarya. Karya pertamanya adalah "Perjalanan Si Binuang" (1974) dengan corak surealis, mempresentasikan Minang yang retak. Sumber lukisannnya berasal dari cerita tambo Minangkabau. Bentuk yang retak sendiri melambangkan manusia dan kehidupannya itu rapuh. Seperti ia mendapat inspirasi keretakan tersebut dari patung tanah liat yang retak terkena panas dan rapuh.

Hampir semua karya Darvies bertemakan Minang yang retak, miris, dan penuh sindiran saat berkarya di Sumatra Barat. Cerita tambo diplesetkan dengan lukisan (tanduak kerbau) Si Binuang, yang berasal dari gunuang Marapi, “mamak kamanakan"(kemanakan) sebagai wujud rasa prihatin pada kondisi adat. Pada tahun 1980-an pelukis yang muncul dengan kecenderungan berbeda adalah Agus Purwantoro (Abstrak dekoratif), Asri Rosidi (kubisme) serta Bodi Dharma (sketsa dan keramik). Di sudut lainnya, kalangan akademik juga sudah banyak seniman yang muncul seperti Musni Ramanto, Idran Wakidi, Gusman Thaha, Ady Rossa, Arbi Samah, dan belasan seniman lainnya.

Setelah kebaruan itu diperkenalkan, hal tersebut bisa dipahami dengan lebih baik sebagai bagian dari sebuah proses sosial di mana jaringan di antara seniman dan para partisipan lain seperti masyarakat seni menjadi terbangun. Sebuah konstruksi seni tersebut terjadi di dalam sebuah konteks sosio-ekonomis seperti diorientasikan oleh kecenderungan-kecenderungan politis. Setelah karyanya dipamerkan dalam ruang publik yaitu pada pameran tunggal pertama Darvies pada tahun 1979 di PKP (Pusat Kesenian Padang), Darvies terlihat sangat gigih mempertahankan dunia seni lukisnya. Ia memilih seniman sebagai profesi utamanya dan penuh usaha dalam berkreasi dan merintis profesi senimannya.

Saat berkarya di Sumatra Barat, bahan pengganti cat minyak yang Darvies gunakan untuk melukis adalah linoli yang biasa digunakan orang untuk cat bendi, (berbasis minyak). Selain menggunakan linoli, juga ia memakai cat besi seperti cat merek "Kuda Terbang". Cara yang digunakan juga khas, yaitu dengan merebus cat merek kuda terbang setelah berbuih-buih minyaknya dibuang dan dengan sendok, dan diambil cat murninya untuk melukis. Saat itu alat dan bahan melukis susah ditemui di Padang. Kalaupun ada, dijual dengan harga yang mahal.

Zolberg mengemukakan bahwa pasar merupakan struktur pendukung penting dalam distribusi seni, yang bertindak sebagai perantara menyalurkan dan mengembangkan karya para seniman (Zolberg, 1990 : 180). Selain Sanggar Bumi, Darvies juga memiliki patron dari pemerintah yaitu pihak Pusat Kesenian Padang (PKP). Hal ini dapat diamati dari pameran Darvies dengan pelukis Asri Rosidi pada tanggal 27 Juni dan 11 Juni 1992 (Singgalang, 29 Juni 1992). Pameran tersebut merupakan kegiatan pertama dari empat program pameran lukisan yang akan direncanakan oleh pihak Taman Budaya Padang untuk anggaran pada tahun 1992/1993.

Dunia seni yang berkembang menyediakan sistem distribusi yang mengintegrasikan para seniman ke dalam ekonomi masyarakat mereka, membawa karya seni ke publik yang menghargai mereka dan akan 
membayar sehingga karya dapat dilanjutkan. Saat itu ia sempat dinyatakan mendapat penghargaan sebagai seniman yang cukup mendapat perhatian dunia seni Sumatra Barat dengan terpilihnya Darvies mendapatkan anugrah seni dari Dewan Kesenian Sumatra Barat pada tahun 1999 berdasarkan hasil kesepakatan para koordinator juri. Namun, penyerahan anugrah tersebut dibatalkan tanpa alasan yang jelas (Haluan, 5 April 1999).

Selain mendapat sponsor oleh PKP, pameran tunggal Darvies yang pertama di Taman Budaya Padang pada tahun 1979 mendapat pendanaan dari Sanggar Bumi yang saat itu juga mewadahi kegitan seni rupa. Saat itu sanggar bumi menjadi penyangga kehidupan melukis seniman yang tergabung di dalamnya. Di Sanggar Bumi, Darvies dan teman-temannya melukis dan saling berdiskusi demi kemajuan kualitas berkarya. Selain itu juga sempat berpameran bersama dengan tema "Tiga Watak" pada tahun 1998 bekerjasama dengan Genta Budaya.

Dalam perjalanan kekaryaanya, Darvies juga mendapat batu sandungan, bahwa tidak semua karyanya mendapat apresiasi dan dukungan dari masyarakat. Karya surealis Minang Darvies mendapat tanggapan negatif dari salah satu masyarakat, yaitu dari ketua LKAM yaitu sebuah Lembaga Kerapatan Adat Minangkabau di Padang. Karyanya yang mendapat kritika keras adalah karya yang memvisualisasikan orang Minang yang retak dan tanpa kepala yang terdapat pada beberapa karya Darvies yang sempat dipamerkan bersama (Haluan, 24 September 1996). Untuk itu, Darvies memberi penjelasan bahwa ia tidak bermaksud menghina orang Minang yang juga keluarganya sendiri. Tetapi bermaksud memberi penyadaran bahwa keberadaaan adat dan jiwa keminangan itu sendiri sudah mulai luntur dan harus dikembalikan ke jalan yang benar kembali (wawancara, 23 November 2014).

Pada periode selanjutnya, Darvies akhirnya menerima tawaran Risman untuk menetap di Yogyakarta. Beberapa karyanya sempat terkena imbas booming seni lukis pada tahun 2007 di Yogyakarta dan beberapa karyanya sempat menjadi cover buku, salah satunya lukisan yang berjudul "Daun Pintu" dan "The Houses of Leaves". Tawaran untuk menjadikan karyanya menjadi cover buku kumpulan puisi dan sastra ini berawal dari tawaran seorang kenalannya di Yogyakarta bernama Ali Syamsudin Arsi. Sebanyak tiga series terbitan buku, ia menjadikan lukisan Darvies menjadi cover. Sehingga selain tetap konsisten dan aktif berpameran serta berkarya, Darvies juga menerima peluang lain pada karya-karyanya selama di Yogyakarta.

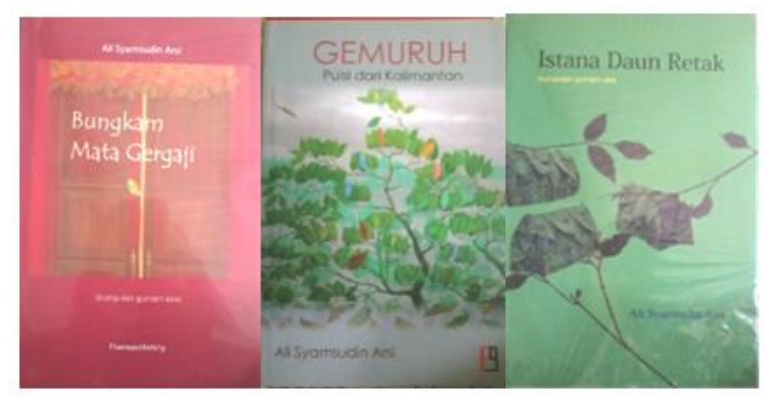

Gambar 7. Lukisan Darvies yang Dijadikan Cover Buku Puisi (Rasjidin, 2014)

Darvies terlihat mengalami pengaruh yang signifikan terhadap iklim berkesenian di Yogyakarya. Saat itu, Iklim berkesenian di sana sudah jauh berkembang menuju ranah praktik berkesenian kontemporer. Sebagai batasan saat distributor memiliki gagasan independen mengenai seperti apa karya seni harusnya atau diminati saat berada di Yogyakarta, Darvies tidak memiliki pengetahuan memadai mengenai kaidah seni tersebut dan mendorongnya untuk membuat pilihan. Darvies memandang permintaan distributor terhadap kriteria karya yang diminati dapat menaikkan nilai pada karyanya secara materil. Ia menerima langganan atau perantara yang memiliki pengetahuan itu sebagai mitra dalam produksi karya seni yaitu saran dari para distributor lukisan di Yogyakarta dan di Jakarta. Sehingga karya Darvies pun berubah. Selanjutnya, persentuhannya yang semakin jauh dengan Minangkabau membuat Darvies kehabisan ide untuk berkarya surealis Minang. Ia tidak lagi menemukan inspirasi untuk berkarya tersebut setelah hijrah ke Yogyakarta. Ia memilih menemukan dunia seni baru dengan memilih corak lukisan yang baru untuk menyesuaikan karyanya dengan iklim yang baru.

Darvies dalam perubahannya berkarya juga mendapat dukungan di Iklim berkesenian di Yogyakarta. Pilihanpilihan kreatifnya saat di Padang, Sumatra Barat yang sekian tahun lalu masih kuat dengan eksotisme simbolsimbol Minang dengan gaya surealis, kini telah memperoleh energi yang baru dalam berkarya menemukan bentuk kreatifitas baru dalam mengeksekusi objek. Darvies perlahan meninggalkan gaya surealis yang biasa ia hadirkan. Temanya lebih pada objek -objek lebih spesifik seperti daun, batu, semut, untuk melihat persoalan lebih global lagi. Terlihat dalam karya "Di Ujung Ranting"(2008), "Imaji tentang Batu (2007)", "8702" (2008) dan karyakarya lain setelah domisili di Yogyakarta. 
Volume 10 Nomor 01 Januari-Juni 2021

p-ISSN: 2301-5942 | e-ISSN: 2580-2380

\section{KESIMPULAN DAN SARAN}

1.Kesimpulan

Proses kre Darvies merupakan pelukis dan juga pemain teater, yang melukis dengan corak surealis di Sumatra Barat. Latar belakangnya dalam perjalanan berkeseniannya didukung oleh intitusi sosial yang berada di sekitarnya, yaitu SSRI Padang, ASRI Yogyakarta, Sanggar Bumi Teater, dan Komunitas Seni Sakato. Aktor-aktor sosial yang berperan dalam relasinya Wisran Hadi pada Sanggar Bumi di Padang dan Risman Marah sebagai temannya di SSRI dan di Yogyakarta. Selanjutnya, faktor-faktor yang memengaruhi perubahan karya Darvies Rasjidin adalah faktor ekonomi sehingga ia memilih untuk merantau. Keberadaan masyarakat Sumatra Barat dan Yogyakarta dalam penyangga dan mengapresiasi profesi Darvies juga memengaruhi kreatifitasnya dalam berkarya. Kondisi sosial yang berbeda dan iklim berkesenian yang berbeda memengaruhi karyanya sehingga tidak konsisten pada corak surealis.

\section{Saran}

Perjalanan berkesenian Darvies dapat dijadikan refleksi dan inspirasi oleh seniman generasi selanjutnya. Penelitian ini yang merupakan upaya pendataan seniman beserta perjalanan kesenian dan kekaryaanya sangat penting untuk didokumentasikan. Perlu adanya kajian lebih mendalam tentang Darvies Rasjisin dan juga seniman-seniman lain yang berkontribusi secara nyata terhadap perkembangan seni rupa di Sumatra Barat yang mungkin belum banyak diteliti ataupun dicatat. Hal ini dharapkan agar sejarah perkembangan seni rupa di Sumatra Barat menemukan konstruksi yang dapat dibaca dan dipelajari oleh lintas generasi. Selain itu, selama penelitian ini berlangsung penulis merasa begitu banyak arsip-arsip sejarah perjalalan seni rupa daerah yang masih banyak terpencar dan dokumentasi seni yang perlu untuk direproduksi ulang dan dikumpulkan. Sehingga, dibutuhkan tangan-tangan peneliti lain untuk meninjau dan menganalisis ke dalam sebuah pengkajian dan penelitian terhadap fenomena seni rupa di Sumatra Barat.

\section{DAFTAR RUJUKAN}

. (1992 September 24). Kehidupan Seni

Lukis Sumbar Memprihatinkan. Singgalang. Informasi Seksi:

Denzin, N. K., \& Lincoln, Y.S. (2009). Handbook of Qualitative Research. Yogyakarta: Pustaka Pelajar.

Fitryona, N. (2017). The Dialectic of Visual Arts Life in West Sumatra 1986-2003. International Journal of Creative and Arts Studies, 4(1), 2739.
Fitryona, N. (2014). "Darvies Rasjidin dan Karya-

Karyanya". Hasil Wawancara Pribadi: 03

Oktober 2014, Yogyakarta.

Fitryona, N. (2014). "Perjalanan Berkesenian Darvies

Rasjidin\#1", Hasil Wawancara Pribadi: 22

November 2014, Yogyakarta.

Fitryona, N. (2014). "Perjalanan Berkesenian Darvies

Rasjidin\#2”, Hasil Wawancara Pribadi: 23

November 2014, Yogyakarta.

Kartodirdjo, Sartono. (1993). Pendekatan Ilmu Sosial

Dalam Metodologi Sejarah. Jakarta :

Gramedia.

Larenz, A., dkk. (2016). Cadiak Indak Mambuang

Pandai. Katalog BAKABA\#5. Kumpulan Karya

Pelukis:

Moenir, Darman. (1979 Juni 21). Catatan Kebudayaan

: Seni Lukis (di) Sumatra Barat. Haluan.

Informasi Seksi:

Moenir, Darman. (1979 Juli 3). Catatan Kecil

Pameran Tunggal Darvies Rasjidin di PKP.

Haluan. Informasi Seksi:

Navis, A. A. (1999 April 5). Tentang Anungrah Seni 1999. Haluan. : 4 (Kol 1-2)

Pamola, D., \& Makoginta, A. R. (2012 Desember 18). Antara Pintu \& Halaman. Katalog BAKABA\#2. Kumpulan Karya Pelukis:

Rasjidin, Darvies. (2014). "Kumpulan Karya-Karya Lukisan”. Hasil Dokumentasi Pribadi: 09 April 2014, Yogyakarta.

Rasjidin, Darvies. (2014). "Potret Diri”. Hasil

Dokumentasi Pribadi: 10 Juni 2018, Yogyakarta.

Yurnaldi. (1992 Juli 7). Ide-Ide Cemerlang Darvies dan Essensi Warna Asri Rosdi. Haluan.

Yusrizal. (1996 September 24). Retak-Retak Bentuk dalam Acuan Minangkabau. Haluan.

Zolberg, Vera L. (1990). Constructing a Sosiology of The Art. New York : Cambridge University Press. 